\title{
The Electoral Process and the 2007 Snap Elections in
} Lesotho

\author{
Fako Likoti (PhD.) \\ National University of Lesotho \\ Department of Political Sciences \\ P.O. Roma, 180 \\ Lesotho
}

\section{Abstract}

Anthony Downs (1957), in his celebrated work, 'An Economic Theory of Democracy', argued, that parties utere political firms in business of selling packnges of policies in order to maximise votes so as to be able to win and enjoy the fruits of government office. While on the other hand voters were political consumers, using their votes as political currency to purchase the public policies on offer at a general election. These zoters zuere not tied to any party but they were rational, maximising, free-thinking and were determined to gain maximum return by voting for a party of their choice. These voters elect a party that offered them the best policy packnge at the lowest tax cost. As it will become clear in this paper, most of the rural voters from 61 constituencies out of a total of 80 in 2007 Lesotho election, elected Lesotho Congress for Democracy (LCD) probably on the basts of Dozens' observations above. LCD popularised free education and a pension scheme policies for the elderly who had never been employed before. The task of this paper is to evaluate this perception in relation to the rational choice theory. The paper will also assess the rational choice model in line with the above description to ascertain whether the LCD, a party that has been winning elections in Lesotho from 1998 to 2007 has been voted on the basis of this model. The paper does not claim that rational choice model will provide a definitive answer to this project, but it will attempt to analyse patterns that may appear to reflect some similarities with the model. However, this would not mean that, by testing this model on LCD policies, the model is beyond criticism since 
mational model is noted for its complexities when applied to empirical cases.

\section{Introduction}

Any assessment of political parties must take into consideration that a political party "refers to an association of citizens who share a set of basic political views that they seek to advance by presenting candidates for elective offices" (Ceaser, 1990:96). Political parties must therefore, be able to respond to the voters' interests and expectations. This is because, "political parties constitute an important element of modern government" (Nnoli, 1986:139). It is only political parties within society, among other social groups, which are able to form modern governments, which translate voters' interests into national policies. It is for this reason that parties compete for power. Similarly, for politiral parties to "win elections they must attract support from many different groups in the electorate" (Crew, 1993:83). This means that they must bring both their current and prospective voter's interests together and create consensus across a large segment of the population. The major reason is that voting is the main aim of an individual to register his opinion regarding his understanding of a particular political system. The voter learns these opinions within his family and his environment, and upon reaching political maturity, she/he tends to identify with various socio-economic interests. When individuals vote, their vote becomes "an expression of individual views of their political outlook" (Rose, 1990: 28). It is this outlook which has played a major role in voting behaviour, because " even in the absence of parties, electors may still vote expressively, using the ethnicity, gender, or religion of Candidates to identify the Candidate who best represents an individual's outlook formed through a lifetime of learning "(Rose, 1990: 29).

The paper is divided into five sections. The next section below provides a contextual background about Lesotho's electoral politics. The third section discusses the LCD 
policies which the party sold to the voters during the 2006 campaign. The fourth section focuses specifically on the factors that might have given the LCD this victory. These include but not limited to the position of an incumbency, the weak financial status of the opposition parties, a factor that might have played a major role in inhibiting these parties campaigning strategy, the legacy and influence of the late Dr. Ntsu Mokhehle, the rational choice model which attempts to explain in an approximated manner why the LCD has been able to win this election. The conclusion sums up the main argument of the debates.

\section{Background}

Since the 1998 election in Lesotho, one party appears to be not only dominating the political landscape, but also winning every election. The Lesotho Congress for democracy (LCD), formed barely eight months before the 1998 election, went on to win this election. The party continued to win both the 2002 election and the 2007 snap elections with a wide margin despite the fact that it fragmented twice into two parties, the Lesotho Peoples' Congress in September 2001 and the All Basotho Convention $(A B C)$ in October 2006. Nonetheless, in 2007 LCD formed an election pact with National Independent Party (NIP). This party has won these elections notwithstanding the fact that it had been labelled as a party with a poor service delivery record in 2006 (Public Eye2006). This inefficiency even forced the $A B C$ leader to form his own party and thus disassociated himself from the LCD (Public Eye2006). Like the past three elections in Lesotho, they were conducted in an atmosphere of peace and tranquillity. In fact, they were declared free and fair by most observers (Matlosa, 2007). For example, both domestic and international observers "declared the electoral process as credible and its outcome as legitimate" (Matlosa, 2007: 16). Despite the above declarations, it is important to indicate that there were some claims received by the Independent 
Electoral Commission that some Ministers were seen convering voters to polling centres. However, the quick action by the IEC officials at both Tse'nola and Lovely Rock polling stations were able to put a stop to this practice which contravened the electoral code of conduct. The two Ministers in question lost their constituencies to the opposition in the end. It was however, not clear whether they lost because people were also against their actions or whether it was because voters in these constituencies had already made up their minds to vote for other parties.

Few months after the 2007 elections, several parties lodged petitions with and against the IEC as well as applications before the High Court of Lesotho. All these were in protest against what was then grievances arising from the elections activities as table 1 below shows; 
154 Review of Southem African Studies Vol. 12, No. 1 \& 2, 2008

\section{Table1: List of Elections Petitions}

\begin{tabular}{|l|l|l|}
\hline PETITION & MATTER & RESULTS \\
\hline Petition 01/07 & $\begin{array}{l}\text { IEC/LWP } \\
\text { Qhalasi Constituency }\end{array}$ & $\begin{array}{l}\text { Dismissed with } \\
\text { costs }\end{array}$ \\
\hline Petition 02/07 & $\begin{array}{l}\text { IEC/Molapo } \\
\text { Thaba-Putsoa } \\
\text { Constituency }\end{array}$ & $\begin{array}{l}\text { Dismissed with } \\
\text { costs }\end{array}$ \\
\hline Petition 03/07 & $\begin{array}{l}\text { IEC/Tsolo } \\
\text { Mafeteng Constituency }\end{array}$ & $\begin{array}{l}\text { Dismissed with } \\
\text { costs }\end{array}$ \\
\hline Petition 04/07 & $\begin{array}{l}\text { IEC/Rafoneke } \\
\text { Machache Constituency }\end{array}$ & $\begin{array}{l}\text { Dismissed with } \\
\text { costs }\end{array}$ \\
\hline Petition05/07 & $\begin{array}{l}\text { IEC/Mokhosi } \\
\text { Bela-Bela Constituency }\end{array}$ & $\begin{array}{l}\text { Dismissed with } \\
\text { costs }\end{array}$ \\
\hline Petition 06/07 & $\begin{array}{l}\text { IEC/Tsiu } \\
\text { Kolonyama } \\
\text { Constituency }\end{array}$ & $\begin{array}{l}\text { Dismissed with } \\
\text { costs }\end{array}$ \\
\hline CIV/APN/116/07 $/$ MFP & $\begin{array}{l}\text { IECmissed with } \\
\text { costs }\end{array}$ \\
\hline CIV/APN $/ 170 / 07$ & IEC/ABC & $\begin{array}{l}\text { IEC served } \\
\text { Applicant with } \\
\text { its answer on } \\
\text { the 7th June } \\
\text { 2007. Applicant } \\
\text { did not reply. } \\
\text { IEC would then } \\
\text { force matters. }\end{array}$ \\
\hline
\end{tabular}

Source: IEC, 2007

All these cases were dismissed with costs except the case involving IEC and $A B C$ which is still in court as reflected in table 1 above. What was worthy of note also was the role of Independent Electoral Commission which ensured that voters and parties alike, have access to unrestricted information regarding this election. For the first time since 1993, the Independent Electoral Commission (IEC) appointed a three-man-Media Monitoring Panel (MMP) to facilitate free access of all the political parties to the national media. The Panel ensured that "all contesting political 
parties have equal access to the public media as provided for in the National election laws especially section $47 \mathrm{~K}$ (1) of National Assembly Act 1992 which states that, "every political party shall have the right to have the substance of its campaign propaganda reported on news broadcasts of Government-owned national media and in any newspaper in circulation in Lesotho" (National Assembly Election Act, 1992).

A series of election development policy debates on both state controlled radios and television (February $3 \& 10,2007$ ) among the Leaders of seven major political parties which had nominated more than 40 candidates for the 2007 elections were facilitated to provide even more coverage for eligible voters to understand each party's manifestos (Santho, Likoti and Sello, 2007). The television debates were carried out live on Lesotho television and Radio Lesotho. The purpose was to ensure that voters understood thoroughly what political parties were saying so that they could make informed choices. This was equally important because the 2007 election was a snap election. Therefore, voters had to be assisted to have unrestricted access to a free and fair media that provided them with alternative impartial information.

The 17th February 2007 election in Lesotho was undoubtedly one of the most extraordinary in recent Lesotho history. This was so for four major reasons as follows: first, for the first time in the political history of Lesotho, the country was faced with snap elections as a direct consequence of fragmentation of the ruling party in parliament. Following this fragmentation in October 2006, the Prime Minister of Lesotho was forced to call for snap elections. The breakaway party, the All Basotho Convention $(A B C)$, left the government of Pakalitha Mosisili with the slimmest of majorities in the 120 -member chamber. The $A B C$ was formed with 18 members of all former LCD parliamentarians who had gained access to parliament through First Past the Post (FPTP) electoral system. This 
crossing of the floor by the $\mathrm{ABC}$ motivated the governing party that was left with 62 members of parliament to call for snap election.

Second, the $A B C$ was led by former Communications Minister Thomas Thabane who was popularly known as "Mr delivery" within the LCD government and in some quarters. Thabane was able to generate unprecedented interest among prospective voters and injected 'developmental issues' into the campaign, a new feature in Lesotho politics. Third, this was an election that provided a rare competitive challenge to the party that has ruled the country for a decade with no credible challenger around. The LCD hegemony appeared to be facing a determined onslaught from its splinter party, the ABC.

Finally, this was the election, which had the poorest voter turnout in the past three elections (1993, 1998 and 2002). For instance, out of a population estimated at 2.2 million people, 916230 had registered to cast their votes. However, only less than half of the registered voters managed to cast their ballots in 2552 polling stations around the country, accounting for a disappointing figure of 442,963 that had voted. Despite this apparent voter apathy the LCD, went on to win 61 out of 80 constituencies. Furthermore, out of 19 political parties that had registered with the Independent Electoral Commission (IEC), only 14 contested elections. This was another clear reflection that it was not only the voters who were apathetic, but also political parties lacked interest to participate in this election. To the consternation of the opinion pollsters, like 'Work for Justice and the Public Eye newspapers,' whose findings throughout the campaign had predicted an $A B C$ victory over the $L C D$, these predictions were proved wrong. Table 2 below illustrates the scale of LCD victory in 2007 election; 
Table 2: The 2007 Lesotho General Elections

\begin{tabular}{|l|l|l|l|l|}
\hline Year & Main Parties & No. of Votes & "//10f Votes & No, of Seats \\
\hline 2007 & LCI /NIP & 229,602 & 68.9 & 82 \\
& ABC/LWP & 107.463 & 22.7 & 27 \\
& BNP & 29,965 & 2.5 & 3 \\
& ACP & 20,263 & 1.7 & 2 \\
& IPFD & 15,477 & 0.8 & 1 \\
& BCP & 9,823 & 0.8 & 1 \\
& MFP & 9,129 & 0.8 & 1 \\
& BDNNP & 8,783 & 0.8 & 1 \\
& BBDP & 8,474 & 0.8 & 1 \\
\hline Notal & 3,984 & 0.0 & 0 \\
\hline
\end{tabular}

Source: Lesotho Independent Electoral Commission

The LCD secured a conformable 61 seats, and its alliance partner, the NIP got 21 proportional seats that accounted for 82 seats in parliament. The LCD/NIP alliance accounted for 68.9 percent while the $\mathrm{ABC}$ and its coalition partner, the Lesotho Workers Party (LWP) got away with 17 constituencies. The Lesotho Workers' Party got 10 proportional seats, which came to 27 seats. The Basotho National Party (BNP), a traditional rival of the LCD emerged fifth with a poor showing of 3 proportional representation seats. The LCD victory surprised many because of the then unfriendly circumstances that made this victory unfeasible as the above mentioned pollsters had predicted. The LCD's success was achieved in most unfavourable circumstances.

First, Lesotho was in a grip of the longest unemployment rate since the early 1980s. The ABC manifesto argued that, unemployment was rampant and stood at " 45 percent, with high child labour, 50 percent of the population live below the poverty line and the United Nations has described 40 percent of the population as ultra poor, meaning that they 
cannot afford food" (ABC, 2007:5). In fact the Minister of Finance in his 2007 budget speech corroborated the $A B C$ claim that the country was facing an economic catastrophe of major proportion:

this unprecedented deteriontion in the land and its people has ushered in a crisis in the social and moral fabric of our society. Unemployment is high, and poverty is deepening; stock theft and armed robbery have become the order of the day; corruption and nepotism are spreading like a cancer in our institutions; and there is no doubt that life is becoming harder by the day for an increasing number of our people (Le'sotho Govermment Budget speech 2007:3).

Furthermore, traditional sources of household incomes, agriculture and migrant work, had been declining. Migrant Labour had also declined from 126,000 in 1987 to 52,000 at the end of 2006. Prospects for agriculture as high yielding enterprises were also threatened by drought and climate change (Lesotho Government Budget speech, 2007). In fact, Lesotho, according to the Finance Minister, has been losing the global race for jobs, high, broad-based and sustainable economic growth and poverty eradication to other countries in SACU, SADC, Africa and Asia (Lesotho Government Budget speech, 2007). Despite these economic hardships, the LCD still won the election.

Second, The Prime Minister had earlier castigated civil servants for not being loyal to the government, saying that they appeared to be attending opposition parties' rallies. He boasted that the government have sufficient support in the country and as such he did not depend on Civil servants votes (Public Eye, 2006: 10). He boldly made this statement even though there was no way of knowing whether they voted for him or not in the last election (2002). This outburst was precipitated by concerns that the government was not delivering services. The civil servants were, therefore, singled out as scape-goats for government failure to deliver 
services (ABC, 2007).

Third, the government had earlier introduced what appears to most people the most unpopular policy that was meant to benefit the Ministers and Senior Government Officials (Public Eye, 2006:2). This policy, allowed the govermment Ministers to purchase Mercedes Benz luxury cars for M4000.00 and Toyota Camries for civil servants in statutory positions for M2000.00 (Government of Lesotho 20016). The Imperial Fleet Services Company previously loaned the vehicles to the government. These vehicles were supposed to be sold to these officials after three years in government operation. The vehicle scheme furore appears to have left a legacy of resentment in a large proportion of the urban voters. This can be deduced from the fact that, for the first time since LCD came to power, it lost all constituencies in the capital, Maseru. Subsequent to the above outcry, the government dispatched a group of senior Ministers to the national television in August 2006. They were to defend the above decision as a legitimate government policy. This was not withstanding the fact that the benefits that went to twenty-six Ministers appeared to be meagre, in comparison with world standards. Lesotho with a small economy and with economic growth (real GDP growth) of 4.5 percent for 2006 (FAO, 2007) and nowhere near macro-economic target of 7 percent per annum, these benefits were perceived as substantial.

In retrospect, around November 1998, Rakoro Phororo, had published an article in the local Newspaper, MophemeThe Survivor, where he strongly disagreed with Prime Minister (PM) Mosisili's government policy of granting the then Prime Minister Ntsu Mokhehle a Mercedes Benz under what now appears to have been similar a circumstance. He wrote:

..in a poor conntry such as Lesotho, this precedent will ever be the main motive for political leaders to aspire to premiership at all costs, even at the expense of sacrificing 
principles, conscience, polutical zalues, and reconciliation. The dilemmon of mediocre political lenders that Lesolho is presently experiencing awill thus get worse in the years ahend (Mopheme-The Surviver1998 Tiuesday, October27November 02)

Phororo's predictions could not be far from correct. The irony is that, Phororo had been appointed a Minister of Agriculture (in the 2002 cabinet), and was now part of a group, which allocated vehicles to senior civil servants and Ministers. During the above television interview, one of the Ministers in reply to questions put to him by journalists was dismissive about the whole furore. Despite several public protestations regarding the manner in which the above vehicles were acquired, the PM, in one of his utterances in March 2006, informed the public gathering in Berea that some people appeared to be making unnecessary noise about the government vehicles scheme. He went on to argue that "Ketla Ba Busa Ho Fihlela Ba Tloaela. Ea Belelang a eo bollella Khaitseli ea Malom'ae"'. (Meaning that I will reign on you until you are accustomed to my premiership. Whoever is in doubt should protest to his uncle). What appears to have been unfortunate on the part of the government has been its failure to acknowledge that government property cannot be transferred to individuals in such a manner. The government is not a corporation but a public entity. Government properties are normally auctioned publicly and proceeds derived thereof channelled to the public purse, not kept for the benefits of some individuals in powerful positions. Minister Phororo in his article above in relation to this government policy of the current PM lamented in 1998 that:

if I was a leader of a government that is sensitive to human misery and national economic tragedy, such as has befallen Lesotho, I and my colleagues would humbly approach our predecessor (PM Mokhehle) and plend with him for us to at least postpone granting of an expensive 
car until the economic situation improves. (Mopheme-The Survour1998 Tuesilny, Octoher27-November 02).

Since Phororo wrote the above article in 1998, economic misery in Lesotho has become worse to say the least. He was against the granting of one car, yet he has become mute about the allocation of twenty six Mercedes Benze cars to Ministers of which he has recently become a member and over ten Camry cars to senior civil servants. He did not suggest for the postponement he eloquently advocated for above when Mokhehle was given a car. He did not even persuade his colleagues that what they were doing was wrong despite the current economic wretchedness that has befallen Lesotho. This vehicle scheme led to the creation of a popular perception which Bratton and Van de Walle equated to that which prevailed in the early 1990s whereby citizen opined that those "with access to political power were living high on the hog while ordinary people suffered"(Bratton and Van de Walle 1997:99).

\section{The LCD Policies and the 2006 Campaign}

It would appear that, the key to the LCD success, centred on the party's ability to convince sufficient voters that both the pension and education policies especially free education policy were extremely important provided that the incumbent government remained in office. According to Work for Justice (2006), the government of Lesotho in 2004 introduced an Old age pension of M150 per month paid to over 70 year olds elderly people, the majority of which live in the rural areas. This pension scheme became a campaign tool for the LCD for the 2007 elections (2007 Election manifesto of the LCD 2007). The elderly men and women who can no longer help themselves were also promised to be paid M200 per month an increase of M50 if they reelected the LCD. The manifesto argued that the party values them greatly because they still possessed a lot of wisdom and insights. The party also promised to deliberate on how 
the facilities at Pay-Points can be improved in order to facilitate the elderly's easy access (2007 Election manifesto of the LCD 2007). It can be assumed for that reason that, most rural people in the 2007 election appeared to have voted according to their economic interests, which were primarily influenced by the above LCD manifesto.

The LCD has always popularised the old pension scheme. Majority of the beneficiaries of the pension scheme have not contributed to it. Most of them have never worked for government before. On the other hand, retired civil servants are not entitled to receive this old age pension. It has been tailor made exclusively for those who were not earning any pension before. This scheme has succeeded in raising individual expectations, a factor that can be attributed to the LCD electoral success. The pension scheme, despite its shortcomings, among other issues remained the main attraction among rural voters. Eventually, "one way in which this pocket-book effect is manifested is through the level of optimism that people exhibit about their financial prospects" (King, 1992:177). The critical question, of course, is how far these changes in individual economic expectation might have affected the popularity of the LCD government. There are certainly good reasons for supposing that they may have done so.

In assessing the rational choice model for the above period it was evident that there was an emerging pattern in support of the model among different groups. The LCD achieved a decisive shift of votes from voters who voted on their economic preferences, more especially on pension factor, which strongly favoured the party. Aided by some of the sympathetic National radio station like MoAfrica FM and Radio Lesotho earlier before the Election Day was declared, the LCD made pension a major issue. This was congruent with RCM theorists who always "draw attention to the significance of issue voting and argue that issues do matter precisely because policy preferences determines the direction of vote choice and not the other way around" 
(Dearlove and Saunders, 2000:164). It is clear that both pension and free education policies were important issues among the voters, more especially the rural voters in Lesotho where LCD won all constituencies.

While the LCD has been widely criticised for failing to deliver on promises of job creation, economic growth and success against HIV/AIDS (the ABC Manifesto 2006), it has urged voters to back it with plans to increase old age pensions. Many studies of relationship between economics and political support have distinguished between

sociotropic' and 'egocentric' motivations. Voters act sociotropically to the extent that their political judgement depends on their assessment of whether the government's economic performance has been good or bad for the country as a whole (Sanders1993: 179).

The pension scheme in Lesotho is indicative of this statement. It was clear that no matter how the government record had been, this was not an important factor to the voters. What was important was the economic status regardless of how meagre the monthly pension of M150 was. Their expression was unequivocal in the voting booth thus: 'I feel good about my own prospects, therefore, I feel good about the LCD government, irrespective of what other parties have been saying'. The LCD government has also been able to maintain inflation at 5 percent and anticipated 3.5 percent economic growth during this fiscal year (Public eye2007 February 23). It was primarily for economic reasons that the voters rewarded the party in office with their votes. They saw it as better than other parties in managing the economy, producing economic prosperity, a sense of wellbeing, and the feel-good factor. According to RCM, voters are prepared to re-elect the government if they feel that it manages the economy in such a way that their future and their children's future will be bright. Former British Prime Minister, Harold Wilson, from the Labour party in 1968, argued that, "all political history shows that the standing of 
the government and its ability to hold the confidence of the electorate at a general election depends on the success of its economic policy" (Dearlove and Saunders, 2000:168). The LCD in Lesotho appears to have done just that.

The LCD government had earlier aimed to provide equitable universal basic education to all. In 2000), it introduced a programme of free primary education, which was to be implemented gradually for over a seven-year period. For the 2007 elections, the party (I.CD) also promised to expand free education for secondary school pupil and provide books for student from poor backgrounds (Election manifesto of the LCD 20(07). Free education remained as popular as ever among the poor peasants in the country. This is because when stakes are high rationality kicks in; this was evident in the 2007 snap elections. Stakes are always high in every election, hence why most people thought they were going to lose both these policies if they voted for a different party. The defining feature of rational choice theory is that people always try to maximize their interests when it comes to things like whom to vote for or whether to volunteer politically. It was for this reason that both the pension and free education policies remained high among the rural voters. The approach has many variants. Decision theory, for example, centres on cost-benefit calculations that individuals make without reference to anyone else's plans. It can be assumed maybe correctly that voters based their decision centred on costbenefit analysis.

Furthermore, government has since 2000 financed free primary education programmes, which saw the first batch graduate at the end of 2006. In fact, in order to strengthen the improvement of education at all levels, the LCD government further promised to allocate M88.4 million to finance activities in the education sector, including provision of infrastructure for the 2007 financial year (Thahane, 2007). The above situation was similar to that of Britain in the early 1990s, where it was found that "voters 
would support the party that would put most money into their pockets. This notion of pocketbook voting, or economic voting, is a more closely specified version of issue voting" (Dearlove and Saunders, 2000:167). The rural voters in Lesotho perceived themselves as making a lot of savings from LCD policies. First, they did not have to pay fees for their children at primary school level. Second, they were being promised not to pay for books for their secondary school children as well. Third, they were still enjoying the M150 monthly pension. Finally, they were promised a further increase of M50 for their pension. It can be argued strongly that RCM was very much at work in Lesotho during the 2007 election. Voters saw LCD government as putting more money in their pockets.

Among other achievements for which the LCD government praised itself during the election campaign were the following; it had entrenched democracy, empowered women in local government, helped to introduce 10 private radio and television stations, built rural roads and created 30,000 new jobs in the past five years (Election manifesto of the LCD 2007). The party also agued that in recent years, garment manufacturing has been the key driver of growth, recording sharp growth of 53 percent in 2001 and maintaining strong pace until 2004, before stalling in 2005, as a result of strong competition from Asia and the appreciation of the Rand/Loti (Thahane 2007). Government took steps to counteract the loss of jobs. In particular, to improve the financial position of firms, a supportive tax regime was introduced in 2006/2007(Election manifesto of the LCD 2007). This action on its own was an indication that the government economic management strategy, was improving and this made most voters optimistic about their future economic well-being about their economic prospects. Firm level training was also introduced to boost employee productivity. Strong support was also received from US importers who have developed innovative programmes for improving production and 
reversing the effects of HIV and AIDS, and continuing imports from Lesotho producers (Thahane, 20(07).

The LCD has pointed toward its foreign policy success, even though this item did not form a major campaigning issue. Lesotho is currently the chair of SADC and it has sent both police and military observers to Darfur, Sudan. Lesotho, under the government of LCD is also a member of African Union Security Committee. The Prime Minister is on record for pointing out that his party has brought peace and stability in the country (Election manifesto of the LCD 2007). As Chair of the SADC region, Lesotho is driving a process of scaling up regional economic integration. In less than one year, the SADC will launch a Free-Trade Area (FTA) within which member states will trade with each other duty-free and quota-free. This will raise significantly the Intra-SADC trade, which now stands around 25 percent (Election manifesto of the LCD 2007). With a population of over 235 million, this would present Lesotho with a huge market that would drive its economic growth rate to a sustainable $7 \%$ per annum (Election manifesto of the LCD, 2007). These were some of the associated factors which might have assisted the party even though they did not feature prominently during the campaign unlike the two policies discussed above.

Nonetheless, the party, which is likely to win elections, is evaluated on its "performance or party program" (Peele et al 1992:64), more especially during the by-elections or by frequently holding the government accountable on all fronts. It is fair to assume that the LCD apart from articulating the above policies, has been able to keep the momentum unlike other parties in contesting every byelection. This has enabled it to make its supporters not to forget it. Table three that follows illustrates the scale of the LCD victories in all by-elections. 
Th' Electoral Process and the 2007 Snap election 167

Table: 3

Lesotho Parliamentary by-elections from February 2003 to February 2005

\begin{tabular}{|c|c|c|c|c|c|c|}
\hline Constituency & $\begin{array}{l}\text { I:lection } \\
\text { Iate }\end{array}$ & $\begin{array}{l}\text { Parties } \\
\text { Participated }\end{array}$ & $\begin{array}{l}\text { Registered } \\
\text { voters }\end{array}$ & $\begin{array}{l}\text { Total } \\
\text { Votes }\end{array}$ & $\begin{array}{l}\text { Voter } \\
\text { lurnout } \\
\end{array}$ & Winner \\
\hline Molete & $\begin{array}{l}15-1 \cdot c b- \\
200.3\end{array}$ & $\begin{array}{l}\text { MHP, [PID, } \\
\text { ICI, BAC, } \\
\text { INI)III:NII: } \\
\text { NI*2. }\end{array}$ & 11,768 & 3,445 & $34 \%$ & $\mathrm{LCD}$ \\
\hline Qhonll & $\begin{array}{l}23-\wedge 11 y_{-} \\
20013\end{array}$ & 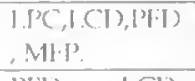 & 10,929 & 3,516 & $.32 \%$ & $L(1)$ \\
\hline Khatung: & $\begin{array}{l}23-\wedge u y- \\
2+x 3^{-}\end{array}$ & 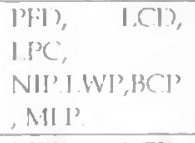 & 11,391 & 4,280 & $38 \%$ & $\mathrm{LC}(1)$ \\
\hline Thathet foutsonat & $\begin{array}{l}2+-\int \text { an- } \\
2(x) 4\end{array}$ & $\begin{array}{ll}\text { MIFI, } & \text { I.CI), } \\
\text { l'll), } & \text { I.WI', } \\
\text { UP. }\end{array}$ & 13,319 & 3,353 & $25 \%$ & LCI \\
\hline Motemposo & $\begin{array}{l}2.4-\Lambda p r- \\
21 \times 4\end{array}$ & 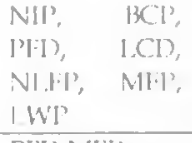 & 13,125 & 1,712 & $13 \%$ & LCI) \\
\hline Woholutio & $\begin{array}{l}\text { 5-Jun- } \\
2004\end{array}$ & 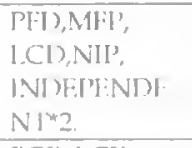 & 9.994 & $1, n(x)$ & $17 \%$ & $\mathrm{LCD}$ \\
\hline (Thenth: & $\begin{array}{l}16-0 \mathrm{CH} \\
2 \mathrm{x}+4\end{array}$ & {$[\mathrm{BCl}, \mathrm{LCl})$} & 11,820 & 3,155 & $27 \%$ & (.Cl) \\
\hline Koro-horo & $\begin{array}{l}12-b e b- \\
2 \ln 15\end{array}$ & $\begin{array}{l}\text { I(I), Nil, } \\
\text { [II]. }\end{array}$ & 9,186 & $2,5+2$ & $28 \%$ & (.CI) \\
\hline 0.110 & $\begin{array}{l}\left(14-\left(X^{-1}-\right.\right. \\
2(4) 5\end{array}$ & $\begin{array}{l}\text { 1.CI),IIII),NII' } \\
\text { INI) } \\
\mathrm{NI}^{*}+\end{array}$ & 7,291 & 856 & $14 \%$ & (.CI) \\
\hline LFHAKI VG & $\begin{array}{l}\text { 22-AI'R- } \\
20(x)\end{array}$ & $1 .(1)$ & 3,867 & $\begin{array}{l}\text { Unoppl } \\
\text { used }\end{array}$ & $\begin{array}{l}\text { Unoppos } \\
\text { ed }\end{array}$ & $\mathrm{LCD}$ \\
\hline
\end{tabular}

Source: Independent Electoral Commission

Judging from several by-elections held since 2002 and the recent general elections, voters' participation has drastically declined. The apparent LCD victory in these by-elections as illustrated by table 3 is a reflection of the party's strength of its past record, a feature which also fits the rational choice model. Some Opposition parties have boycotted these byelections, still this gave LCD more mileage over them. For instance, on the 25 th April 2005, a member of the ruling LCD for Lebakeng constituency was sworn into parliament as a new MP. What was significant about the swearing in of $\mathrm{Mr}$. 
Tse'mane Sokatle was that he got into parliament unopposed. While most of these by-elections were won by the ruling $L C D$, it was nevertheless with a very low margin as illustrated in table 3 above because there was no credible contender.

\section{Factors that led to the Victory of LCD in 2007 Elections}

Several factors were alleged to have assisted this party (LCD) to win the elections. Chief among these was the incumbency. The fact that LCD was a ruling party, it had occupied the most advantageous position. It was this position which enabled the party to campaign using state resources across the country unlike the opposition parties which had none and depended on meagre resources from their supporters' subscriptions. After the 2002 election, the ruling party introduced constituency secretaries for all the members of Parliament who won the constituencies. This ensured that in all these 80 constituencies, there is a paid up secretary who serves members of Parliament including one opposition member who won one constituency. This made certain that the ruling party with its $79 \mathrm{MPs}$ is able to function at the grassroots level unlike most opposition parties with their 40 Proportional Representation (PR) MPs whom the government did not extend this financial facility. In amending the 1998 Members of parliament Salaries Act in 2003, the government argued that, "Proportional representation MPs do not represent the electorate but their parties. So they cannot be given constituency allowances because they have no constituencies" (Makoa, 2005: 63).

Another factor which hindered opposition parties' performance in 2007 election was the issue of finance as alluded to above. Lack of party funding has made it difficult for opposition parties to mount aggressive campaigns country wide, consequently giving the incumbent LCD more mileage. Party funding is crucial for political parties to function efficiently and effectively. In Lesotho, parties were given campaign funding, but not party funding for the first 
time cluring 2002 general elections. This campaign funding is done through the Independent Electoral Commission. Each political party taking part in this election was given M20, 000.00 . This money was disbursed in two phases; firstly, each party was given M10, 000.00. The remaining amount was awarded in proportion to the number of candidates each party had fielded for the election (Matlosa \& Sello 2005). Most of the opposition parties in Lesotho, like the NPP, NIP, PFD and BAC could not even field candidates throughout the country during the 2002 elections. The issue of party funding in Lesotho has been complicated by lack of legislation. This is because,

...prizate funding to political parties remains unregulated. Lack of legislated party funding and unregulated private funding adversely affects parties and their activities. This is more so for opposition parties ( $L P C, B N P, N I P, B A C, P F D)$ than the ruling party LCD, given that the latter does have access to public resources by virtue of its incumbency (Matlosa E Sello 2005: 47).

These parties therefore depend heavily on paltry contributions from members. This means that they cannot undertake their party programmes effectively because these subscriptions tend to be unreliable. Financial weakness is one of the main limitations of opposition parties. Same parties have cited lack of funds as a reason for nonparticipation in by-elections.

Lesotho political situation as far as political parties' finances are concerned, is similar to that of Ghana where opposition parties have experienced,

... financial roenkness translated into meagre or nonexistent formal party organisation. None of the opposition parties in 1995 maintained offices in all the regions or most of the districts. At the grassroots, these parties were represented, if at all, by volunteers 
in makeshift offices or prizate homess. ()nly the governing ND) (National Democratic Congress) had offices in all ten regions and in ozer 90 percent of the constituencies (Sundbrook, 200(): 119)

Seven opposition parties in Lesotho have no permanent offices except the main opposition, BNP, BCP and LPC. Nonetheless, these parties since 2002 election have not maintained offices in all three regions of the country including its districts. The above situation since 2002, has changed only in respect of the ruling LCD because it had maintained secretariat services at the constituency level including LPC constituency. Like the NDC in Ghand, the LCD has been able to service its constituents unlike most opposition parties which lack these facilities.

On the other hand, opposition parties in Lesotho appear to have failed to develop a viable opposition to the ruling LCD. All the nine opposition parties in the legislature during the 2002 parliament remain divided internally and among themselves. They have been unable to think outside of the box and find consensus in order to discredit the ruling party before prospective voters. These opposition parties appear to have faltered in attracting voters. They remained unviable because they have not been able to develop or offer viable policies that will enable them to attract more voters. Most of these parties' leadership is composed of people with primary education and as such have not been able to attract requisite expertise. Lack of expertise makes them unable to develop good policies. Therefore, they practice rhetoric politics and unable to address real issues. For that reason, "a parliamentary opposition would only be viable if it is able to weave a policy programme capable of attracting the support of a diverse set of constituencies, and in particular the growing community of independent voters" (Habib and Taylor 2000: 56).

The other factor that can be accounted for LCD victory revolves around the founder leader of LCD who was also a 
founder leader of BCP. Mokhehle wielded considerable power over the BCP in the early 1950s. He was feared and at the same time worshipped by both his enemies and followers. According to former BCP stalwart, Ts'eliso Makhakhe', the BCP derives its inspiration and motive power from the philosophy of egalitarianism and PanAfricanist outlook. The philosophy of egalitarianism denotes that the party has a strong peasant base and obligation. Its leadership is uniquely of peasant origin and background, and its roots are firmly set in the harsh rural environment and experiences rather than in elitist and aristocratic circumstances and comfort.

Since the LCD broke off from the BCP, it was also alleged that the party took with it these values. It was further claimed that the LCD leaders were in good position to liberate the peasants, the labouring masses, the unemployed with their offspring on the fringes of towns and throughout the country from the vicious cycles of ignorance, poverty and wretched misery for they have themselves been born and bred in similar circumstances. Again, because of the wisdom enshrined in the African custom of the extended family, they cannot escape involvement in the events and experiences affecting the next-of-kin and others such as illness, death, weddings, and dead miners' wives claiming compensation or reparation from the mine, children's schooling and fees, counselling and other socio-economic problems. It was these values which most rural voters appear to have been holding on to that made the LCD more electable in most rural constituencies.

Third, Mokhehle's name has become a brand name. In fact, it has become a vote winner. It took hard work for Mokhehle to establish himself as a household name in Lesotho politics since the late 1940s. It is currently difficult to know or understand the leader of LCD and the Prime Minister Mosisili as well as his former Deputy, the leader of Lesotho People's Congress (LPC) and now the interim 
leader of the Alliance of Congress Parties (ACP) Kelebone Maope in Lesotho politics except for the fact that both men were associated with Ntsu Mokhchle. The two men are quite aware that they cannot identify themselves before the Lesotho voter without invoking Mokhehle's name and most importantly using him and particularly his picture as a vote catcher. The dead man's head is extremcly important as a vote winner for these parties. This is the man (Mokhehle) who devoted his social life and his being to Lesotho politics. Anything that bears his name is a quick seller to Lesotho electorates so the above men believe. This was one of the reasons why the LCD has been winning elections because of the party's association with Mokhehle.

Mokhehle's personality cult is as strong as ever. In all their public gatherings, both LPC" and LCD invoke Mokhehle. Similarly, LPC political News Paper and their election symbol in 2002 was Mokhehle's head while LCD News paper and election symbol is an "Eagle" (Meaning Ntsu "in the local language" the first name of the late Leader Ntsu Mokhehle). In fact, "Ntsu Mokhehle, the energetic and well educated BAC "meader, was widely regarded as a charismatic figure" (Weisfelder1999:8). Again, all the 27MPs, who formed LPC including Mokhehle's brother after their defection from the LCD in 2001 were regarded "as Mokhehle's die hard supporters who have been in exile with him except its current interim leader (Mosisili) in 2001. Thus, Mokhehle's personality cult assisted the LCD to win elections in Lesotho. Conversely, all parties that broke off from BCP and LCD are finding it difficult to win elections despite using Mokhehle's magic name other than the LCD. This means that there might be something more to this LCD victory than the magic from Mokhehle. The major question therefore, is why voters continue to vote for LCD in these elections?

There are myriad theories in Political science literature. Some of these theories can be used to explain the LCD victory. The most prominent are theories of voting 
behaviour. These include but not limited to sociological model, which emphasises the social groups voting patterns, the party identification model that stresses the individual's psychological attachment to his environment and the rational choice model which argues that voters are rational and vote according to their preferences (Denver1989, 1992, Dunleavy1990, Miller 1990), is the one the paper will focus upon in analysing the LCD victory in 2007 elections.

The rational choice model (RCM) which goes with various names such as "issue voting model, a value model, rational choice theory, rational action theory, a prospective model (if votes fit best with attitudes towards party policies for the future), a retrospective model (if votes fit best with attitudes towards the government's past record in handling the economy, for example, or a leader personality model' (Miller 1992:53). RCM is the dominant theoretical paradigm in microeconomics. It is also central to contemporary political science thinking. In recent years, the theory has more increasingly been used in political science, sociology and other academic disciplines than in economics. The theory is a paradigm, a hypothesis or a framework used for understanding and often modelling a political (social), and economic behaviour of individuals. It has had far-reaching impacts on the study of political science, especially in fields like the study of interest groups, elections, behaviour in legislatures, coalitions, and bureaucracy (Dunleavy 1991).

Most models have additional assumptions. Proponents of rational choice models do not claim that a model's assumptions are a full description of reality, only that good models can aid reasoning and provide help in formulating falsifiable hypotheses, whether intuitive or not. Successful hypotheses are those that survive empirical tests (Dunleavy 1991). It is in this context that the model is used in this paper to analyse the 2007 LCD election victory. In fact, Models that rely on rational choice theory often adopt methodological individualism, the assumption that social situations or collective hehaviours are the result of individual actions. 
While most models of rational choice are very diverse, they share one thing in common. They all assume that individuals choose the best action according to stable preference functions and constraints facing them. This choice is exercised whenever a voter is confronted with a decision, whether the snap election or choosing among various parties, the model assumes that given this diversity of choices the voter will still be able to exercise his or her choice by ensuring that he or she derives maximum benefits from the choice made. The RCM applies same assumptions used by economists in analysing voting behaviour. The model argues that a consumer "operating in an economic market has a finely divisible stock of money to distribute over a wide variety of goods in order to express his or her preferences in a sophisticated and gradual way"(Dunleavy, 1985: 12). This consumer has only one vote to spend to a party that comes closest to his choice and he buys a basket full of policies. The model does not address the question of where voters got their attitudes of voting from or how they got them, but focuses on their attitudes and choice in voting. It claims "Voters make up their own minds about issues, performance and personalities and then vote for the party that comes closest to delivering the policies and performance they want "(Dunleavy, 1990:53). The voters individually act rationally when choosing to vote for a particular party and maximise their vote to derive most benefits available from their vote.

Voters have clear knowledge of past record of parties' policies and "are as volatile as shoppers choosing between supermarkets constantly in search of a better product"(Crewe 1993:110). The voters have enormous information at their disposal. This information provides them with various alternatives in comparing their parties' preferences and helps them in reaching their voting decisions. The voters therefore, "after comparing parties with their own preferred outcomes, they choose the party closest to their preferences"(Dunleavy, 1985:13). The rational 
voters' views are clearly consistent with political issues. They know roughly what options are available by ranking these issues and choosing the one which best suits voters. Therefore, voters, according to this model are egoistic and entirely self-interested.

Rational decision making entails choosing an action given one's preferences, the actions one could take, and expectations about the outcomes of those actions (http:/ / en.wikipedia.org/wiki/Rational_choice_theory).

Actions are often expressed as a set, for example a set of $j$ exhaustive and exclusive actions: $\mathrm{A}=\left\{a_{1}, \ldots, a_{i}, \ldots, a_{i}\right\}$. For example, if a person is to vote for either Roger, Sara, or abstain, her set of possible voting actions is:

$A=\{$ Roger, Sarn, abstain $\}$. Individuals can also have similar sets of possible outcomes. Rational choice theory makes two assumptions about individuals' preferences for actions. First, is the assumption of completeness, that is, that all actions can be ranked in an order of preference (indifference between two or more is possible). Second, is the transitivity, the assumption that if action $a_{1}$ is preferred to $a_{2}$, and action $n_{2}$ is preferred to $a_{3}$, then $a_{1}$ is preferred to $a_{3}$. Together these assumptions form the result that given a set of exhaustive and exclusive actions to chose from, an individual can rank them in terms of his/her preferences, and that his/her preferences are

consistent

(http:/ / en.wikipedia.org/wiki/Rational_choice_theory).

Nevertheless, there are many formulae for this model. This paper therefore, is an attempt to understand why this party has been wimning so many elections (1998, 2002 and 2007) despite noticeable political challenges in Lesotho as explained below.

The LCD victory may be explained by borrowing some of the important aspects of the rational choice model above. In his analysis of the RCM, Crew (1993) argued that, the molel involve three different judgments about political parties. For instance, the issue of unemployment, makes voters judge parties by their policies for job creation (policy 
voting), by their degree of emphasis on the problem at hand (priority-voting) or by their past record on unemployment (performance-voting). The LCD has been vocal in pointing out the fact that it has been able to relieve the poor by providing free education and pension for the elderly (Policy voting). It also placed much emphasis on increasing monthly pension (priority-voting) if voted into power again and of course the fact that it has been able to create many jobs (performance-voting) during the their tenure. These similarities appeared very close to Crew analysis above.

The LCD had exploited every possible means available to increase voters' confidence in the party and also being able to convince enough electorates that it was competent in managing the economy better than other parties. It would appear that $A B C$ and other major opposition parties such as the Basotho National Party (BNP) and Alliance of Congress Parties (ACP) were not trusted. This was similar to 1983 and 1987 situation in Britain whereby Labour party and other Alliance parties were defeated by Conservative party because they were seen as divided, adventuristic and despite their good policies, voting for them was seen as a waste vote. In the same manner, the $A B C$ had just fragmented from LCD four months before polling day as a result of intra-party conflict. Similarly, the BNP had just experienced a split into Basotho Democratic Party (BDNP), while ACP was a coalition of former congress parties of which one of them broke away from LCD before. It can be argued therefore, that voters did not have confidence in the leadership of these parties, instead, decided to vote for the party that they saw as capable of managing the economy, just as the British voted conservative party in 1992 instead of Labour party on assumption that Conservative was more capable to run the economy than Labour. LCD also managed to raise voters' expectations of being better off under the LCD government because expectations played a significant role in determining the level of support for the government during the 2007 period. 
Nevertheless, the rational choice model like all others has some problems. It explains very little about class and partisanship de-alignment. This model is too theoretical and very difficult to apply in practice because of the nature of voters' unpredictable decisions. The major problem has been that it is often hard to ascertain whether a particular attitude is a cause of certain behaviour or these attitudes constitute rationalisation. When rational model is closely scrutinised, its case of cause and effect becomes very weak. It can only be said that this pocket-book voting might have likely created conducive conditions for the LCD to win 2007 general elections, but the evidence available has not been compelling enough to justify this conclusion.

While hunger has been a major $A B C$ issue, in its manifesto, this policy appears not to have favoured the party by attracting more votes. It does not appear to have translated into a major swing throughout the country except the capital city alone where the party won seventeen constituencies (IEC 2007 results). What was significant in this period was that the rise in unemployment an estimated 40 to 45 percent during 2002 parliament did inflict a small cmount of damage on government's electoral fortunes, though clearly not enough to prevent its re-election. The 2007 election reflected a new pattern of attitudes in voting, "more voters treated elections as an occasion for personal choice, not class or parental loyalty "(Budge, 1993: 100) among parties in Lesotho. Nevertheless, the LCD policies appeared to have been instrumental in influencing voters' preferences.

\section{Conclusion}

While there are varied explanations for this LCD victory, which include among others, the position of the incumbency, lack of financial resource for opposition parties, the legacy of former Prime Minister Ntsu Mokhehle both the founder of BCP and LCD and finally, the rational choice theory which appears to come closest in providing a 


\section{Rerrieze of Southern Africun Studies Vol. 12, No. 1 \& 2, 2008}

plausible explanation of this victory and in illuminating patterns of voting behaviour in Lesotho. By the same token, it should not be assumed that the model is problem free. All in all, criticisms of the flowering rational choice research program are not completely without merit, but neither are they debilitating. Given the heterogeneity of the political science profession, it would be surprising if any one approach won general acceptance. The approach itself remains debated by all scholars and in some cases such as Lesotho, it has been relatively insightful while in others it has provided less than plausible explanation about LCD victory. The paper is therefore, part of the on-going debate about the theory in explaining elections.

In conclusion therefore, we argue that there is evidence, which indicates that rational choice model had been applied in the 2007 elections. Most rural voters in Lesotho still regard the $L C D$ as more competent in managing the economy than other parties, hence they prefer to vote for this party on assumption that they would be better off under the LCD administration which advocates pension for the elderly, free education and economic prosperity. Therefore, rational choice model still plays a major role in voting more especially in 2007 elections. Rational choice model comes closest in explaining why the LCD won the 2007 election.

It is also safe to conclude that the two LCD policies; the pension scheme and free education paid dividends to the party. These policies appear to have attracted most votes especially among the poor rural peasants who find education expenses too high and pension scheme as supplementing their near zero income from their poor subsistence farming. These rural voters regard free education as a relief to their dire economic status, thus pocket book voting was the main factor that made them to vote for the LCD. Indeed, they voted for the party that put more money in their pockets and they used their votes as 
political money to buy policies of the party they preferred as Downs (1957) argues above.

It is of course, as rational to vote for an income as for a pension that one did not work for since majority of voters in the rural areas are unemployed and depend to a greater extent on both the monthly pension and free primary education or for policies to reduce poverty and improve economic conditions as the LCD manifesto promised. In fact, rational choice theorists would probably regard voting for the party best able to advance one's family's economic prosperity as rational voting par excellence. 


\section{References}

All Basotho Convention. (2007) Election Manifesto 2007. Maseru: ABC NEC

Bratton, M. and Van de W. N. (1997) Democratic Experiments in Africa: Regime Transitions in Compunatione Perspective. Cambridge: Cambridge University Press.

Budge, I. and McKay, D. (3rt, ed). (1993) The Dereloping British Political System the 1990's. London: Longman.

Crewe, I. (1993) Voting and Electorate. In Deoclopment in British Politics 4. Dunleavy Patrick ed. London: The Macmillan Press Ltd.

Dearlove, J. and Saunders P. (3rd ed),(2000) Introduction to British Politics. Cambridge; Polity press.

Denver, D. (1989) Elections And Voting Behaviour in Britain. London; Philip Allen Publishers.

..(1992) Issues And Controversies in British Voting Behaniour. (London; Harvester Wheatsheaf.

Downs, A. (1957) An Economic Theory of Democracy. New York: Harper and Row.

Dunleavy, P. (1985) British Democracy at The Cross Ronds: Voting Anl Party Competition In The 1980's. London; George Allen\& Unwin.

..........., (1990) Development In British Politics 3. London; Macmillan.

(1991). "Democracy, Burenucracy and Public Choice: Economic Models in Political Science". London: Pearson.

FAO. (2007) Global Information and Early Warning System on Food and Agriculture World Food Programme Special Report to Lesotho, 12 June.

Habib, A. and Taylor R. (2000) Poltical Allinnces and Parliamentary Opposition in Post-Apartheid South Africa: In Conference on 'Opposition in South Africa's New Democracy'. Hosted at Kariega Park in the Eastern Cape, 28-30 June.

King, A. (ed), (1992) Britain at the Polls 1992. Newjersy; Chartham House Publishing Inc. 
Lesotho Congress for Democracy. (2007) 2007 Election Manifesto for the LCD. (Maseru; LCD NEC).

Matlosa, K. (2007) 'The 2007 General Election in Lesotho: Managing the Post-Election Conflict'. A paper prepared for a conference on Lesotho's 2007 general Election: Towards a Constructive Management of post-Election Disputes Maseru Sun Cabanas Hotel, 25-27 September. Organised by The Institute of Southern African (EISA) and the Lesotho Council of Non-Governmental Organisation (LCN).

and Sello, C. (2005) Political Parties and

Democratisation In Lesotho. In EISA Research Report No 23.

Miller, W.L. (ed), (1990) Voting and the Electorate. In Development in British Politics 3. Dunleavy Patrick et al, ed. London; Macmillan.

Mopheme-The Survizior, Tuesday October27-November 02, 1998

Public Eye March 27, 2006.

November 10, 2006.

February 232007

National Assembly Election Act 1992.

Rational Choice Theory. Available in

http://en.wikipedia.org/wiki/Rational choice theory

(October102007).

Rose, R. (1990) The Loyalties Of Voters: A Lifetime Learning Model. London; Sage Publications.

Sandbrook, R. (2000) Closing the Circle: Democratisation and Development in Africa. London and New York: Zed Books.

Sanders, D, (1993) 'Why the Conservative Party Won Again'. Britain at the Polls1992. In Anthony King et al edit. New Jesery; Chatham House Publishers, Inc.

Santho, S. Likoti, F.J. and Sello C. (2007) The 2007 Elections Faculitation Program for Sustninable Democratic Governance in Lesotho: Reflections and Lesotho. Maseru: Moruo Consultancy. 
Thahane, T. T. (2007) Budget Speech to Parliament for the 2007/2008 Fiscal Year, Parliament of the kingdom of Lesotho: Conducive investment climate essential for sustainable economic Growth, job creation and poverty reduction. (Maseru, Lesotho).

The government of Lesotho car ownership scheme: an explanatory note, 28 august 2006.

Work for Justice October 2006. 


\section{End Notes}

1 Mr. Tseliso Makhakhe was a prominent founder member of the BCP in the earlv 1950s. He went to exile in Botswana with Mokhehle and others. I le later became a Minister of Education after 1993 and remained with the BCP after the LCD broke off in 1997 as the BCP leader.

"L..PC fragmented from the LCD in 2001 and LCD had fragmented from $B C P$ in 1997. However, during the 2007 elections the $L P C$ and $B A C$ a party which also fragmented from BCP merged and formed Allience of Congress Parties ACP. This parties still subscribe to the original Mokhehle BCP ideology.

14 BCP after its inception in 1952 was known as Basutoland African Congress and the name was later changed to BCP in the early 1960s. 


\section{@) $\mathbb{\oplus \Theta \Theta}$}

This work is licensed under a

Creative Commons

Attribution - NonCommercial - NoDerivs 3.0 License.

To view a copy of the license please see:

http://creativecommons.ora/licenses/bv-nc-nd/3.0/

This is a download from the BLDS Digital Library on OpenDocs

http://opendocs.ids. ac.uk/opendocs/ 